\title{
Vitamino D stoka gali didinti astmos tikimybę
}

\author{
Laura Tamašauskienė, Brigita Šitkauskienė \\ LSMU MA Pulmonologijos ir imunologijos klinika
}

Reikšminiai žodžiai: astma, vitaminas D.

Santrauka. Pastaruoju metu mokslo literatūroje aprašomas vitamino D vaidmuo îvairių ligų patogenezèje. Plačiai tyrinejjama šio vitamino įtaka ir astmai. Tyrimai rodo, kad pacientu, sergančių astma, kraujyje nustatoma mažesnè vitamino D koncentracija nei sveikiems asmenims. Manoma, kad vitaminas D didina imuninès sistemos komponentų, kurie pasižymi uždegimą slopinančiomis savybèmis, kiekį. Keliama hipotezė, kad vitamino D vartojimas sergant astma galètų turèti teigiamos įtakos šios ligos eigai. Straipsnio tikslas - apžvelgti vitamino D savybes bei jo įtaką astmai.

\section{IVADAS}

Vitaminas D yra riebaluose tirpus vitaminas, kurio pagrindinè funkcija - kalcio ir fosforo reabsorbcija plonosiose žarnose bei inkstuose ir dalyvavimas kaulo mineralizacijos procese $[1,2]$. Šiuo metu atliekama daug mokslinių tyrimų, kurie atskleidžia naujas šio vitamino savybes. Manoma, kad vitaminas D dalyvauja onkologinių, endokrininių, širdies ir kraujagyslių, psichikos, autoimuninių ir alerginių ligu patogenezèje $[3,4,5]$. Mokslininkai daug diskutuoja apie vitamino D vaidmeni ir sergant astma [3, 6-8].

Tyrimai rodo, kad vaikų ir suaugusiųjų, sergančių astma, kraujyje vitamino D kiekis yra mažesnis nei sveikų asmenu [6-8]. Manoma, kad vitaminas D veikia T limfocitus, didina interleukino (IL) 10, pasižyminčio uždegimą slopinančiomis savybėmis, kiekị [7, 9, 10]. Kvėpavimo takų epitelio ir lygiưjų raumenų ląstelèse išsidèstę vitamino D receptoriai, kurie yra svarbūs verčiant neaktyvią vitamino D formą 25-hidroksivitaminą D (25(OH)D) ì aktyvią 1,25-dihidroksivitaminą D $(1,25(\mathrm{OH}) \mathrm{D})$, kuris turi uždegimą slopinančių savybių $[11,12]$. Šio straipsnio tikslas apžvelgti vitamino D savybes bei jo įtaką astmai.

\section{VITAMINO D METABOLIZMAS}

Vitaminas D i žmogaus organizmą patenka per odą arba žarnyną [13]. Odoje vyksta 7-dehidrocholesterolio (7-DHC) virsmas i previtaminą $\mathrm{D}_{3}$, veikiant saulès ultravioletinei B spinduliuotei. Previtaminas D3 odoje virsta vitaminu D3, patenka i odos kapiliarus ir susijungia su vitaminą D jungiančiu baltymu [13]. Žarnyne absorbuojamas su maistu ar papildais gautas vitaminas D2 (ergokalciferolis) arba vitaminas D3 (cholekalciferolis). Iš žarnyno rezorbavęsis vitaminas D per limfinę sistemą patenka ị kraują [13].
Vitaminas D3, susijungęs su ji jungiančiu baltymu, yra pernešamas $\mathfrak{i}$ kepenis ir paverčiamas $25(\mathrm{OH}) \mathrm{D}$. Šis patenka i kraujotaką, vèl susijungia su vitaminą $D$ jungiančiu baltymu ir yra nunešamas $\mathfrak{i}$ inkstus, kur virsta aktyvia forma 1,25(OH)2D [13]. Parathormonas, kalcis, fosforas, fibroblastu augimo faktorius 23 ir pats $1,25(\mathrm{OH}) 2 \mathrm{D}$ turi itakos 1,25(OH)2D kiekiui [13]. Fermentas 25-hidroksivitaminas D-24-hidroksilazè suardo tiek $25(\mathrm{OH}) \mathrm{D}$, tiek 1,25(OH)2D i biologiškai neaktyvią, vandenyje tirpstančią kalcitrioninę rūgštị [13]. Vitamino D metabolizmas apibendrintas paveiksle.

Norint nustatyti vitamino D atsargas organizme, rekomenduojama tirti $25(\mathrm{OH}) \mathrm{D}$, nes šios formos gyvavimo trukmé ilgesnè nei $1,25(\mathrm{OH}) 2 \mathrm{D}$ [13].

\section{VITAMINAS D IR ASTMA}

Mokslininkai teigia, kad yra tiesioginis ryšys tarp vitamino D kiekio ir astmos $[6-8,13]$. Eksperimentiniai tyrimai rodo, kad vitaminas D sergant astma slopina eozinofilų telkimąsi, mažina IL-5 kiekį, lygiụjų raumenų proliferaciją [13, 14]. Vitamino D stoka skatina uždegimo savybes turinčių IL-6 ir IL-8 sekreciją [14]. Manoma, kad šis vitaminas didina IL-10 kiekị ir turi įtakos gliukokortikoidų veikimui: papildomai pridejjus vitamino $\mathrm{D}$ i CD4 ${ }^{+} \mathrm{T}$ ląstelių kultūrą, gautą iš astma sergančių pacientų, atspariu gliukokortikoidams, nustatyta didesnė IL-10 sekrecija, prilygstanti pacientų, jautrių gliukokortikoidams, sekrecijai [10, 13, 14]. Vitaminas D sustiprina ir deksametazono indukuotos mitogenu aktyvinamo baltymo (MAP) kinazès fosfatazès-1 raišką periferinio kraujo mononuklearinèse ląstelèse [13]. Pastebèta, kad vitamino D kiekis serume turi neigiamą ryši su gliukokortikoidų vartojimu, t. y. vartojant vitaminą $\mathrm{D}$, mažejja gliukokortikoidų poreikis [13].

Dar 1988-1994 m. vykdytas tyrimas, ì kuri ịtraukta daugiau nei 14 tūkst. pacientų, sergančių astma, atskleidé, 


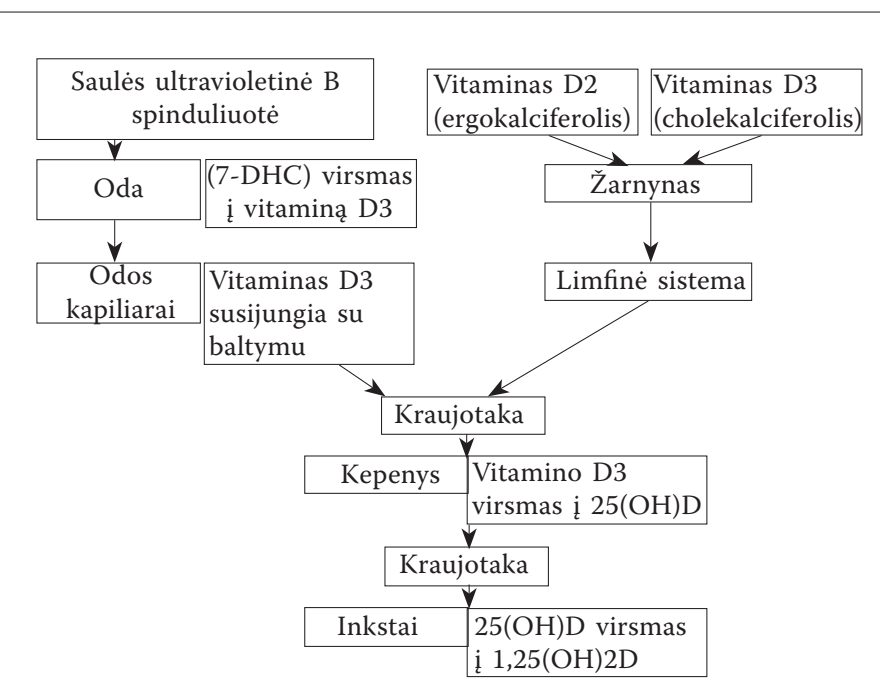

Pav. Vitamino D metabolizmas [13]

kad tiems tiriamiesiems, kurių vitamino D kiekis buvo didžiausias, nustatyti statistiškai reikšmingai didesni plaučių funkcijos rodikliai [13]. Vèliau buvo paskelbta ir daugiau tyrimų, kuriuose nustatytas tiesioginis ryšys tarp vitamino D koncentracijos ir plaučių funkcijos rodiklių [6, 15]. Vitamino D poveikis sergant astma apibendrintas lentelèje.

Daugëjant mokslinių tyrimų, pagrindžiančių vitamino D reikšmę autoimuninių ir alerginių ligų patogenezeje, keliama hipotezè, kad pacientams, sergantiems astma, papildomai skiriamas vitaminas D galètų sumažinti gliukokortikoidų poreikị, pagerinti plaučių funkciją, slopinti uždegimą kvėpavimo takuose ir lygiųjų raumenų proliferaciją. S. Arshi su bendr. teigia, kad pacientams, sergantiems lengvos ar vidutinio sunkumo eigos astma, papildomai vartojantiems vitaminą $\mathrm{D}$, forsuoto iškvejpimo tūris per 1-ą sekundę $\left(\mathrm{FEV}_{1}\right)$ pagerejja po 24 savaičių [16]. $2013 \mathrm{~m}$. paskelbtas Danijoje atliktas tyrimas, kuriame néščios moterys vartojo vitaminą D, - stebèta, ar jų vaikai sirgs alerginèmis ligomis [17]. Vaikai buvo stebimi iki 7-erių metų amžiaus. Tyrimas atskleidè, kad tų moterų, kurios gavo didesnes vitamino D dozes, 7-erių metų vaikai rečiau sirgo astma [17]. Kiti autoriai nurodo, kad moterų, per něštumą gavusių didžiausią vitamino D kiekị, vaikams sumažèjo švokštimo rizika [13]. 2015 m. publikuotos metaanalizès duomenimis, vaikams, sergantiems astma, didelès vitamino D dozès (500-2000 TV per dieną) reikšmingai sumažina astmos paūmèjimų skaičiuc [18].

\section{APIBENDRINIMAS}

Moksliniai tyrimai rodo, kad astma sergančių pacientuc kraujyje nustatomas mažesnis vitamino D kiekis nei sveikų asmenų. Manoma, kad vitaminas D pasižymi uždegimą slopinančiomis savybėmis, didina uždegimą slopinančių savybių turinčių citokinų (IL-10) kiekị bei mažina uždegimo mediatorių (IL-5, IL-6, IL-8) koncentraciją, slopina lygiųjų raumenų proliferaciją, eozinofilų telkimąsi, didina jautrumą gliukokortikoidams, mažina šių vaistų poreikị, astmos paūmèjimų skaičių ir gerina plaučių funkciją. $\mathrm{Pu}-$
Lentelè. Vitamino D poveikis sergant astma [6, 7, 9, 10, 13-15]

\begin{tabular}{l}
\hline$\uparrow$ IL-10 \\
\hline$\downarrow$ eozinofilų telkimąsi \\
\hline$\downarrow$ lygiụjų raumenų proliferaciją \\
\hline$\downarrow$ IL-5 \\
\hline$\downarrow$ IL-6 \\
\hline$\downarrow$ IL-8 \\
\hline$\uparrow$ jautrumą gliukokortikoidams \\
\hline$\uparrow$ plaučių funkcijos rodiklius \\
\hline
\end{tabular}

blikuoti tyrimai, kuriuose aprašomas teigiamas papildomai vartojamo vitamino $D$ poveikis gydant astma sergančius pacientus, ypač vaikus. Taip pat yra duomenų, kad nèščioms moterims profilaktiškai skiriant vitaminą $\mathrm{D}$, sumažeja astmos rizika jų vaikams. Kol kas nèra oficialių rekomendacijų dèl vitamino D skyrimo astmos gydymui ir profilaktikai, bet nuolat atsiranda vis daugiau įrodymų apie šio vitamino palankų poveikị ligos eigai.

\section{LITERATŪRA}

1. Ryan JW, Anderson PH, Turner AG, Morris HA. Vitamin D activities and metabolic bone disease. Clin Chim Acta. 2013;425:148-52.

2. Michael F. Holick, M.D., Ph.D. Vitamin D Deficiency N Engl J Med 2007; 357:266-81.

3. Brown SD, Calvert HH, Fitzpatrick AM. Vitamin D and asthma. Dermatoendocrinol. 2012;4(2):137-45.

4. Muehleisen B, Gallo RL. Vitamin D in allergic disease: Shedding light on a complex problem. J Allergy Clin Immunol. 2013;131(2):324-9.

5. Székely Jl, Pataki Á. Effects of vitamin D on immune disorders with special regard to asthma, COPD and autoimmune diseases: a short review. Expert Rev Respir Med. 2012;6(6):683-704

6. Alyasin S, Momen T, Kashef S, Alipour A, Amin R. The relationship between serum 25 hydroxy vitamin d levels and asthma in children. Allergy Asthma Immunol Res. 2011;3(4):251-5.

7. Maalmi H, Berraïes A, Tangour E, Ammar J, Abid H, Hamzaoui K, Hamzaoui A. The impact of vitamin $D$ deficiency on immune $T$ cells in asthmatic children: a case-control study. J Asthma Allergy. 2012;5:11-9.

8. Ehlayel MS, Bener A, Sabbah A. Is high prevalence of vitamin D deficiency evidence for asthma and allergy risks? Eur Ann Allergy Clin Immunol. 2011;43(3):81-8

9. Ingram JL, Kraft M. IL-13 in asthma and allergic disease: asthma phenotypes and targeted therapies. J Allergy Clin Immunol. 2012;130(4):829-42.

10. Urry Z, Chambers ES, Xystrakis E, Dimeloe S, Richards DF, Gabryšová L, Chris tensen J, Gupta A, Saglani S, Bush A, O'Garra A, Brown Z, Hawrylowicz CM. The role of 1a,25-dihydroxyvitamin D3 and cytokines in the promotion of distinct Foxp3+ and IL-10+ CD4+ T cells. Eur J Immunol. 2012;42(10):2697708.

11. Wittke A, Chang A, Froicu M, Harandi OF, Weaver V, August A, Paulson RF Cantorna MT. Vitamin D receptor expression by the lung micro-environment is required for maximal induction of lung inflammation. Arch Biochem Biophys. 2007;460:306-13.

12. Iqbal SF, Freishtat RJ. Mechanism of action of vitamin D in the asthmatic lung. J Investig Med. 2011;59(8):1200-2.

13. Searing DA, Leung DYM. Vitamin D in Atopic Dermatitis, Asthma and AIlergic Diseases. Immunol Allergy Clin North Am. 2010;0(3):397-409.

14. Poon AH, Mahboub B, Qutayba Hamid Q. Vitamin D deficiency and severe asthma. Pharmacol Ther. 2013;140(2):148-55.

15. Sutherland ER, Goleva E, Jackson LP, Stevens AD, Leung DY. Vitamin D levels, lung function, and steroid response in adult asthma. Am J Respir Crit Care Med. 2010;181(7):699-704

16. Arshi $S$, Fallahpour $M$, Nabavi $M$, Bemanian MH, Javad-Mousavi SA, Nojom M, Esmaeilzadeh H, Molatefi R, Rekabi M, Jalali F, Akbarpour N. The effects of vitamin $D$ supplementation on airway functions in mild to moderate persistent asthma. Ann Allergy Asthma Immunol. 2014;113(4):404-9.

17. Maslova E, Hansen S, Jensen CB, Thorne-Lyman AL, Strøm M, Olsen SF. Vitamin $D$ intake in mid-pregnancy and child allergic disease - a prospective study in 44,825 Danish mother-child pairs. BMC Pregnancy Childbirth 2013;13:199.

18. Pojsupap S, Iliriani K, Sampaio TZ, O'Hearn K, Kovesi T, Menon K, McNally JD. Efficacy of high-dose vitamin $D$ in pediatric asthma: a systematic review and meta-analysis. J Asthma. 2015;52(4):382-90. 